Jurnal BASTRA (Bahasa dan Sastra) : http://ojs.uho.ac.id/index.php/BASTRA

\title{
DEIKSIS DALAM NOVEL KIDUNG DARI NEGERI APUNG KARYA ARSYAD SALAM
}

\author{
OLEH \\ Gusti Ayu Made Sukariani ${ }^{1}$, Sri Suryana Dinar ${ }^{2}$, dan La Ino ${ }^{3}$ \\ ${ }^{1}$ Alumni Jurusan Pend. Bahasa dan Sastra Indonesia, ${ }^{2,3}$ Dosen Jurusan Pendidikan \\ Bahasa dan Sastra Indonesia, Fakultas Keguruan dan Ilmu Pendidikan \\ Universitas Halu Oleo
}

\begin{abstract}
ABSTRAK
Penelitian ini berjudul "Deiksis dalam Novel Kidung dari Negeri Apung Karya Arsyad Salam". Adapun masalah dalam penelitian ini adalah bagaimana penggunaan deiksis dalam novel Kidung dari Negeri Apung karya Arsyad Salam? Penelitian ini bertujuan untuk mendeskripsikan tentang penggunaan deiksis dalam novel Kidung dari Negeri Apung karya Arsyad Salam. Jenis penelitian ini adalah penelitian kepustakaan dengan menggunakan metode deskriptif, artinya menganalisis data yang ditemukan secara deskriptif. Pengumpulan data dalam penelitian ini dengan teknik baca catat. Analisis data dilakukan dengan menggunakan pendekatan pragmatik dengan beberapa tahapan, yaitu mengidentifikasi, mengklasifikasikan data, menganalisis data, dan menyimpulkan hasil analisis data. Berdasarkan analisis data yang telah dilakukan, ditemukan 140 data terdiri dari deiksis persona 90 data, deiksis tempat 14 data, deiksis waktu 18 data, deiksis wacana 12 data, dan deiksis sosial 6 data. Bentuk deiksis persona yang ditemukan yaitu bentuk saya, aku, -ku, ku-, kita, kami, kamu, kalian,dan dia,. Bentuk deiksis tempat, yaitu di sini, di sana, di situ, dan ke sini. Bentuk deiksis waktu, yaitu kemarin, tadi, dan nanti. Bentuk deiksis wacana, yaitu bentuk itu dan bentuk -nya. Bentuk deiksis sosial, yaitu bentuk beliau, pak, dan bapak.
\end{abstract}

Kata Kunci : pragmatik, novel, deiksis 


\section{PENDAHULUAN \\ 1.1 Latar Belakang}

Pragmatik adalah studi tentang makna yang disampaikan penutur (penulis) dan ditafsirkan oleh pendengar (pembaca). Tipe studi ini melibatkan penafsiran tentang apa yang dimaksudkan orang di dalam suatu konteks khusus dan bagaimana konteks itu berpengaruh terhadap apa yang dikatakan. Dalam kajian pragmatik, untuk mengetahui makna bahasa yang diucapkan seseorang tidak bisa hanya dengan mengetahui makna kata dan hubungan gramatikal antar kata saja, tetapi juga harus menarik kesimpulan yang akan menghubungkan apa yang dikatakan dan apa yang diasumsikan, atau apa yang telah dikatakan sebelumnya.

Salah satu bagian dari kajian pragmatik adalah deiksis. Istilah deiksis berasal dari bahasa Yunani Kuno yaitu deiktikos yang bermakna "hal penunjuk secara langsung, berpindah, atau berganti-ganti" tergantung siapa yang menjadi pembicara dan tempat dituturkannya kata-kata tersebut. Dalam pragmatik, kajian deiksis dibagi menjadi lima, yaitu deiksis persona, deiksis tempat, deiksis waktu, deiksis wacana, dan deiksis sosial. Penggunaan deiksis dalam bahasa Indonesia dapat ditemui dalam dua ragam bahasa, yaitu bahasa tulis dan lisan. Dalam bahasa tulis atau tuturan tidak langsung dapat dilihat melalui deskripsi dari pengarang, sedangkan dalam bahasa lisan atau percakapan langsung dapat dideskripsikan secara pragmatik dengan adanya situasi penutur dan lawan tutur.

Peneliti tertarik memilih menganalisis deiksis dalam novel karena ingin memperkenalkan kepada pembaca bahwa dalam karya sastra khususnya novel banyak mengandung komponen bahasa, seperti halnya deiksis. Deiksis menjadi pelengkap dalam penulisan sebuah cerita. Alur cerita novel yang bersifat panjang akan bersifat monoton jika diceritakan begitu saja tanpa menggunakan deiksis di dalamnya. Oleh karena itu, peneliti ingin mendeskripsikan deiksis dalam novel Kidung dari Negeri Apung karya Arsyad Salam.

Novel Kidung dari Negeri Apung merupakan sebuah karya prosa oleh Arsyad Salam yang menceritakan tentang kehidupan masyarakat Bajo. Novel ini merupakan karya lokal Sulawesi Tenggara. Di dalam novel tersebut menceritakan tentang seorang tokoh bernama Liana yang selalu ingin memperjuangkan pendidikan yang baik untuk anak-anak yang ada di kampungnya, di tengah pemikiran masyarakat Bajo yang mayoritas menganggap bahwa pendidikan itu tidak penting.

Data sementara yang diperoleh dari novel Kidung dari Negeri Apung karya Arsyad Salam, yaitu:

(1.)“Aku bertemu kapal penampung Djayanti. Mereka bilang mereka dari Banggai. Sepertinya ikan mereka sedikit," Leman melanjutkan tanpa menunggu komentar awing.

(2.) "Ikan memang sedikit sekarang. Aku heran, ke mana semua ikanikan itu pergi," Awing menjawab datar. Matanya menyipit melihat perahunya yang tertambat di tiang rumah di kolong rumah panggung mereka. (Salam, 2015: 12-13)

Dari data tersebut, terdapat kata aku dan mereka. Kata aku pada kalimat pertama merupakan deiksis persona pertama tunggal yang referennya mengacu pada Leman. Sedangkan, kata aku pada kalimat 
kedua merupakan deiksis persona pertama yang referennya mengacu pada Awing. Kata mereka pada kalimat pertama merupakan deiksis persona ketiga jamak yang referennya mengacu pada orang-orang di kapal penampung Djayanti. Sedangkan, kata mereka pada kalimat kedua merupakan deiksis persona ketiga jamak yang referennya mengacu pada Awing dan Leman. Jadi, deiksis merupakan kata yang tidak memiliki referen yang yang tetap, referennya dapat berubah sesuai dengan konteks dituturkannya.

Jika ditinjau dari ilustrasi yang telah dipaparkan sebelumnya, dalam sebuah novel atau cerita fiksi lainnya sangat membutuhkan penggunaan deiksis yang tepat. Karena deiksis akan menghilangkan sifat monoton dalam sebuah cerita yang panjang. Oleh karena itu, peneliti tertarik menganalisis mengenai deiksis dalam novel Kidung dari Negeri Apung karya Arsyad Salam, untuk memaparkan dan mendeskripsikan jenis-jenis deiksis yang digunakan dalam novel tersebut.

\subsection{Rumusan Masalah}

Berdasarkan uraian latar belakang di atas, maka masalah yang dapat dirumuskan dalam penelitian ini, yaitu bagaimanakah jenis-jenis deiksis dalam novel Kidung dari Negeri Apung karya Arsyad Salam?

\subsection{Tujuan Penelitian}

Tujuan yang diharapkan dari penelitian ini yaitu untuk mendeskripsikan jenis-jenis deiksis dalam novel Kidung dari Negeri Apung karya Arsyad Salam.

\subsection{Manfaat Penelitian}

Berdasarkan tujuan penelitian, maka manfaat dari hasil penelitian ini adalah sebagai berikut:

a) menambah pengetahuan masyarakat atau pembaca mengenai jenis-jenis deiksis dan penggunaannya dalam sebuah wacana, khususnya dalam novel.

b) menjadi perbandingan bagi peneliti-peneliti lainnya yang akan menganalisis hal yang sama dalam bidang linguistik, khususnya yang ingin meneliti tentang deiksis.

\section{KAJIAN PUSTAKA}

\subsection{Hakikat Pragmatik}

Definisi mengenai pragmatik banyak dikemukakan oleh beberapa tokoh pragmatik. Menurut Yule (2014: 3), pragmatik adalah studi tentang makna yang disampaikan oleh penutur (atau penulis) dan ditafsirkan oleh pendengar (atau pembaca). Dardjowidjojo (2012: 26) juga menyatakan bahwa pragmatik bukanlah salah satu komponen dalam bahasa, ia hanyalah memberikan prespektif kepada bahasa. Levinson (dalam Putrayasa, 2014: 1) memberikan dua pengertian tentang pragmatik yang dikaitkan dengan konteks, yaitu (a) pragmatik adalah kajian ihwal hubungan antara bahasa dan konteks yang digramatikalisasikan dan dikodekan dalam struktur bahasa, dan (b) pragmatik adalah kajian ihwal kemampuan pengguna bahasa untuk menyesuaikan kalimat dengan konteks sehingga kalimat itu patut atau tepat diujarkan. Carnap dalam Surastina juga menjelaskan bahwa pragmatik mempelajari konsep-konsep abstrak dan mempelajari hubungan konsep yang merupakan tanda. 


\subsection{Hakikat Novel}

Karya sastra berkembang atas dasar teori, kritik dan sejarah sastra dan dengan sendirinya teori, kritik, sejarah itu memperoleh kehidupan atas dasar karya sastra. Dengan kata lain, kedudukan para pengarang sebagai pencipta karya sastra tidak lebih hebat (dan juga tidak lebih rendah) dari pada posisi peneliti atau kritikus yang mempelajari berbagai masalah kesastraan dengan kaidahkaidah akademis (Yudiono, 2007: 10).

\subsection{Unsur-Unsur Novel \\ 2.3.1 Unsur Intrinsik}

Unsur intrinsik adalah unsurunsur yang membangun karya sastra dari dalam. Unsur-unsur ini dapat dibedakan antara satu dengan yang lainnya, tetapi sukar untuk dipisahkan. Menurut Nurgiyantoro (2013: 30), "Unsur-unsur intrinsik merupakan unsur-unsur yang membangun karya sastra itu sendiri. Unsur-unsur inilah yang menyebabkan karya sastra hadir sebagai karya sastra, unsur-unsur yang secara faktual akan dijumpai jika orang membaca karya sastra." Pada umumnya para ahli membagi unsur intrinsik karya sastra yang salah satunya novel atas latar cerita, alur, tokoh, sudut pandang, gaya bahasa, amanat, dan tema.

\subsubsection{Unsur Ekstrinsik}

Wellek dan Werren (dalam Nurgiyantoro, 2013: 30-31) mengatakan bahwa unsur ekstrinsik terdiri dari sejumlah unsur antara lain:

a) biografi pengarang, keadaan subjektivitas individu pengarang yang memiliki sikap, keyakinan, dan pandangan hidup dapat mempengaruhi karya tulisnya dengan kata lain pengarang juga akan turut menentukan corak karya yang dihasilkannya. b) psikologi baik yang berupa psikologi pengarang (yang mencakup proses kreatifinya), psikologi pembaca, maupun penerapan prinsip psikologi dalam karya dapat mempengaruhi sebuah karya fiksi.

c) keadaan lingkungan pengarang seperti ekonomi, politik dan sosial juga akan berpengaruh terhadap karya sastra.

d) pandangan hidup suatu bangsa, berbagai karya seni yang lain dapat mempengaruhi terhadap karya sastra.

\subsection{Pengertian Deiksis}

Salah satu bagian dari kajian pragmatik adalah deiksis. Istilah deiksis berasal dari bahasa Yunani Kuno yaitu deiktikos yang bermakna "hal penunjuk secara langsung, berpindah, atau berganti-ganti" tergantung siapa yang menjadi pembicara dan tempat dituturkannya kata-kata tersebut. Dalam pragmatik, kajian deiksis dibagi menjadi lima, yaitu deiksis persona, deiksis tempat, deiksis waktu, deiksis wacana, dan deiksis sosial.

\subsection{Jenis-Jenis Dieksis}

Menurut Nababan (dalam Putrayasa, 2014: 43), deiksis ada lima macam, yaitu deiksis persona, deiksis tempat, deiksis waktu, deiksis sosial, dan deiksis wacana.

\subsubsection{Deiksis Persona}

Istilah persona berasal dari kata Latin persona sebagai terjemahan dari kata yunani prosopon, yang artinya topeng (topeng yang dipakai oleh seorang pemain sandiwara), berarti juga peranan atau watak yang dibawakan oleh pemain sandiwara. Istilah persona dipilih oleh ahli bahasa waktu itu disebabkan oleh adanya kemiripan antara peristiwa bahasa dan 
permainan bahasa (Lyons dalam Putrayasa, 2014: 43).

Contoh:

(1) Andi: "Aku mau meminjam buku ceritamu."

(2) Rani: "Aku tidak membawanya sekarang. Kamu datang saja ke rumah sebentar sore".

\subsubsection{Deiksis Persona Pertama}

Kata ganti persona pertama ialah kategori rujukan penutur kepada dirinya sendiri atau kelompok yang melibatkan dirinya sendiri. Dengan kata lain, kata ganti orang pertama merujuk pada pembicara. Kata ganti orang pertama, yaitu saya, aku, kita, dan kami. Kata ganti persona ini dibagi menjadi dua, yaitu kata ganti persona pertama tunggal dan kata ganti persona pertama jamak (Putrayasa, 2014: 43). Selain kata ganti persona pertama tunggal, dalam bahasa Indonesia juga ada kata ganti persona pertama jamak, yakni kami dan kita. Bentuk persona kami dan kita juga memiliki perbedaan. Kami bersifat eksklusif, artinya bentuk persona itu mencakup pembicara/penulis dan orang lain dipihaknya. Tetapi tidak mencakupi orang lain dipihak pendengar/pembacanya. Sebaliknya, kita bersifat inklusif, artinya bentuk persona itu mencakupi tidak saja pembicara/penulis, tetapi juga pendengar/pembaca, dan mungkin pula pihak lain (Putrayasa, 2014: 44).

\subsubsection{Deiksis Persona Kedua}

Deiksis persona kedua adalah rujukan pembicara kepada lawan bicara. Deiksis persona kedua terbagi menjadi dua sama halnya dengan deiksis persona pertama, yaitu deiksis persona kedua tunggal dan deiksis persona kedua jamak. Deiksis persona kedua tunggal mempunyai beberapa bentuk, yakni engkau, kamu, anda, kau-, dan -mu. Bentuk kau- dan -mu merupakan variasi dari bentuk engakau dan kamu.

Contoh:

(1) "Kamu mau bekerja sebagai pemulung?" ujar ibunya kepada Andi.

(2) "Kamu mau pergi ke mana, Seli?"

\subsubsection{Deiksis Persona Ketiga}

Menurut Putrayasa (2014: 45), deiksis atau kata ganti persona ketiga merupakan kategorisasi runjukan pembicara kepada orang yang berada di luar tindak komunikasi. Kata ganti persona ketiga terbagi menjadi dua, yaitu kata ganti persona ketiga tunggal dan kata ganti persona ketiga jamak. Kata ganti persona ketiga tunggal, yaitu bentuk ia, dia, -nya, dan beliau.

Kata ganti persona ketiga jamak adalah mereka. Bentuk mereka berbeda dengan kata ganti persona ketiga dalam acuannya. Pada umumnya, bentuk pronominal persona ketiga hanya untuk merujuk insani. Akan tetapi, pada karya sastra bentuk mereka kadang-kadang dipake untuk merujuk binatang atau benda yang dianggap bernyawa (Putrayasa, 2014: 45).

\subsubsection{Deiksis Tempat}

Deiksis tempat pemberian bentuk pada lokasi menurut peserta dalam peristiwa bahasa. Jika sesuatu yang ditunjuk berada dekat dengan si pembicara digunakan kata sini . jika sesuatu yang ditunjuk berada agak jauh dengan si pembicara digunakan kata situ. Jika sesuatu yang ditunjuk berada jauh dengan si pembicara digunakan kata sana. Karena menunjuk lokasi, pronomina penunnjuk tempat sering digunakan dengan preposisi pengacu arah, di/ke/dari, sehingga membentuk 
beberapa pronomina penunjuk tempat, yaitu di sini, ke sini, dari sini, di situ, ke situ, dari situ, dan di sana, ke sana, dari sana (Putrayasa, 2014: 48). Merujuk pada sebuah hotel, sedangkan pada kalimat (2) merujuk pada pedesaan.

\subsubsection{Deiksis Waktu}

Dalam tatabahasa, deiksis ini disebut adverbial waktu, yaitu pengungkapan kepada titik atau jarak waktu dipandang dari saat suatu ujaran terjadi, atau pada saat seorang penutur berujar (Putrayasa, 2014: 50). Putrayasa (2014: 50) menjelaskan bahwa sebagaimana batas deiksis, yang mempunyai referen yang tidak tetap, deiksis waktu pun mengacu kepada rentang waktu yang dapat berubah-ubah. Kata sekarang mengacu kepada saat penutur berbicara sampai dengan waktu yang sangat panjang tetapi tidak jelas batasnya.

\subsubsection{Deiksis Wacana}

Deiksi wacana merupakan rujukan kepada bagian-bagian tertentu dalam wacana yang telah diberikan atau yang sedang dikembangkan. Berbeda dengan deiksis-deiksis lainnya, yang mengacu kepada referen tertentu meskipun referen itu berubahubah, deiksis wacana harus dirumuskan dengan terlebih dahulu melihatnya di dalam sebuah wacana tertentu (Putrayasa, 2014: 51).

\subsubsection{Deiksis Sosial}

Deiksis sosial ialah rujukan yang dinyatakan berdasarkan perbedaan kemasyarakatan yang mempengaruhi peran pembicara dan pendengar. Perbedaan itu dapat ditunjukan dalam pemilihan kata. Dalam beberapa bahasa, perbedaan tingkat sosial antara pembicara dengan pendengar yang diwujudkan dalam seleksi kata dan/atau sistem morfologi kata-kata tertentu (Nababan dalam Putrayasa, 2014: 53). Dalam bahasa Indonesia hal itu tampak, misalnya dalam penggunaan kata sapaan kamu, kau, anda, saudara, anda, tuan, bapak, ibu, dan sebagainya.

\section{METODE DAN TEKNIK PENELITIAN}

\subsection{Metode dan Jenis Penelitian}

Metode yang digunakan dalam penelitian ini adalah metode deskriptif kualitatif. Metode deskriptif dilakukan untuk menyajikan data secara rinci mengenai deiksis dalam novel Kidung dari Negeri Apung karya Arsyad Salam sebagai objek penelitian. Dikatakan kualitatif karena dalam menjelaskan konsep-konsep yang berkaitan satu sama lain dengan menggunakan kata-kata atau kalimat bukan dengan angka-angka. Berdasarkan objek yang dikaji penelitian ini termasuk jenis penelitian kepustakaan yaitu dengan jalan mengadakan studi lewat bahan bacaan atau referensi yang relevan serta mendukung penelitian ini. Zaim (2014: 18) menyatakan bahwa penelitian perpustakaan (library research), yaitu penelitian yang hanya dilakukan di kamar kerja peneliti atau di perpustakaan dimana peneliti memperoleh data penelitiaannya lewat buku-buku atau sumber informasi pustaka lainnya.

\subsection{Data dan Sumber Data}

\subsubsection{Data}

Data yang digunakan dalam penelitian ini adalah data tertulis, yakni berupa kata dan kalimat yang memuat deiksis dalam novel Kidung dari Negeri Apung karya Arsyad Salam. 


\subsubsection{Sumber Data}

Sumber data dalam penelitian ini adalah novel Kidung dari Negeri Apung karya Arsyad Salam yang diterbitkan di Jakarta oleh Gramedia Pustaka Utama pada April 2015, dengan tebal 192 halaman.

\subsection{Teknik Pengumpulan Data}

Teknik yang digunakan dalam penelitian ini adalah teknik baca catat. Teknik baca yaitu dengan cara membaca dan menganalisis novel Kidung dari Negeri Apung karya Arsyad Salam. Sedangkan, teknik catat yaitu dengan cara mencatat datadata yang telah diperoleh dari hasil bacaan sesuai dengan permasalahan dalam penelitian. Langkah-langkah yang dilakukan dalam teknik penelitian ini yakni sebagai berikut:

a. Membaca novel Kidung dari Negeri Apung karya Arsyad Salam.

b. Mencatat semua data mengenai deiksis dari hasil pembacaan novel Kidung dari Negeri Apung karya Arsyad Salam yang telah ditandai.

c. Klasifikasi data, yaitu dengan cara mengelompokkan data-data yang diperoleh berdasarkan masalah.

d. Deskripsi data, yaitu penggambaran atau pemaparan data yang telah dikelompokkan.

\subsection{Teknik Analisis Data}

Analisis data dilakukan dengan menggunakan pendekatan pragmatik, Kasher (dalam Putrayasa, 2014: 1) mendefinisikan pragmatik sebagai ilmu yang mempelajari bagaimana bahasa tersebut digunakan dan bagaimana bahasa diintegrasikan ke dalam konteks. Analisis data dilakukan melalui beberapa tahap, yaitu mengidentifikasi, mengklasifikasikan data, menganalisis data, dan menyimpulkan hasil analisis data.

\section{HASIL PENELITIAN DAN PEMBAHASAN}

\subsection{Deiksis Persona}

\subsubsection{Deiksis Persona Pertama}

\subsubsection{Deiksis Persona Pertama} Tunggal

Deiksis persona pertama tunggal ialah kategori rujukan penutur kepada dirinya sendiri. Berdasarkan data yang diperoleh jumlah frekuensi penggunaan persona pertama tunggal akan dipaparkan pada tebel 4.2 berikut.

Tabel Frekuensi Penggunaan Bentuk

Deiksis Persona Pertama Tunggal

\begin{tabular}{|c|c|c|}
\hline No & $\begin{array}{c}\text { Bentuk } \\
\text { Deiksis } \\
\text { Persona } \\
\text { Pertama } \\
\text { Tunggal }\end{array}$ & $\begin{array}{c}\text { Frekuensi } \\
\text { Penggunaannya }\end{array}$ \\
\hline 1. & saya & 30 \\
\hline 2. & aku & 32 \\
\hline 3. & ku- & 2 \\
\hline 4. & $-k u$ & 2 \\
\hline \multicolumn{2}{|c|}{ Jumlah } & 70 \\
\hline
\end{tabular}

Bentuk saya merupakan deiksis persona pertama tunggal yang rujukannya mengacu pada si penutur. Deiksis persona pertama tunggal bentuk saya biasa digunakan dalam situasi formal ataupun resmi. Data mengenai deiksis persona pertama tunggal bentuk saya adalah sebagai berikut.

(5) "...Kenapa dengan anak saya?" (hlm. 28) 6) "Saya mau daftarkan dia masuk sekolah." (hlm. 28)

Berdasarkan konteksnya data (5) dan (6) merupakan percakapan antara ibunya Ahmad dan Liana. Liana datang ke rumah Ahmad untuk meminta izin kepada ibunya agar Ahmad dapat ikut masuk sekolah. Pada data (5) kata saya merujuk pada ibunya Ahmad. Ia bertanya kepada 
Liana karena Liana datang ke rumahnya mencari anaknya. Pada data (6) kata saya merujuk pada Liana. Tuturan tersebut dituturkan oleh Liana ketika ia ingin minta izin kepada ibunya Ahmad.

1) Deiksis persona pertama tunggal bentuk aku

Deiksis persona pertama tunggal bentuk aku digunakan dalam konteks ujaran nonformal, misalnya tindak ujar antara dua orang yang saling mengenal dan menunjukan keakraban hubungannya. Data deiksis persona pertama tunggal bentuk aku adalah sebagai berikut.

(1) "Aku bertemu kapal penampung

Djayanti..." "Mereka bilang mereka dari Bagai. Sepertinya ikan mereka sedikit," Leman melanjutkan tanpa menunggu komentar Awing. "Ikan memang sedikit sekarang. (2) "...Aku heran, ke mana semua ikanikan itu pergi," (hlm. 13)

Berdasarkan konteksnya, data (1) dan (2) merupakan percakapan antara Leman dan Awing. Leman bercerita kepada Awing bahwa ia melihat kapal penampung Djayanti yang membawa sedikit ikan. Data (1) terdapat kata aku yang merujuk pada tokoh Leman. Bentuk aku merupakan salah satu bentuk deiksis persona pertama tunggal. Penggunaan kata aku pada data (1) menunjukan situasi yang tidak formal karena penutur dan lawan tutur memiliki hubungan saudara dekat. Pada data (2) terdapat kata aku yang merujuk kepada Awing. Penggunaan kata aku pada data (2) menunjukkan situasi yang tidak formal karena penutur dan lawan tutur memiliki hubungan saudara dekat.

\subsubsection{Deiksis Persona Pertama Jamak}

Tabel Frekuensi Penggunaan Bentuk

Deiksis Persona Pertama Jamak

\begin{tabular}{|c|c|c|}
\hline No & $\begin{array}{c}\text { Bentuk Deiksis } \\
\text { Persona } \\
\text { Pertama Jamak }\end{array}$ & $\begin{array}{c}\text { Frekuensi } \\
\text { Penggunaannya }\end{array}$ \\
\hline 1. & kita & 4 \\
\hline 2. & kami & 2 \\
\hline \multicolumn{2}{|c|}{ Jumlah } & 6 \\
\hline
\end{tabular}

Deiksis persona pertama jamak bentuk kita bersifat inklusif, artinya bentuk persona itu mencakupi tidak saja pembicara atau penulis, tetapi juga pendengar atau pembaca, dan mungkin pula pihak lain. Data mengenai deiksis persona pertama jamak bentuk kita adalah sebagai berikut.

(1) "Ati, atur piring untuk tamu kita ini." (hlm. 111)

(2) “...yang memiliki semangat untuk maju tanpa melupakan falsafah kita sebagai orang Sama," (hlm. 111)

Berdasarkan konteksnya, data (1) dan (2) merupakan tuturan yang terjadi ketika Awing dan Liana datang ke rumah Sandro Dama. Sandro Dama menyuruh Ati untuk menyiapkan makaanan untuk Awing dan Liana. kemudian Sandro Dama melanjutkan bercerita dengan Awing dan Liana. Dari data (1) terdapat kata kita yang merupakan deiksis persona pertama jamak karena merujuk pada penutur yang lebih dari satu. Kata kita digunakan untuk mewakili tokoh Sandro Dama dan Ati. Pada data (2) merujuk pada tokoh Sandro Dama, Awing, dan Liana. Penggunaan kata kita pada data (1) dan (2) untuk menyatakan dua orang yang sedang berdekatan antara penutur dan lawan tutur. 
2) Deiksis persona pertama jamak bentuk kami

Deiksis persona pertama jamak bentuk kami bersifat eksklusif, artinya bentuk persona itu mencakup pembicara atau penulis dan orang lain dipihaknya. Data mengenai deiksis persona pertama jamak bentuk kami adalah sebagai berikut.

(3) "Ya, beginilah. Kami, orang pantai, mau kerja apa lagi kalau bukan di laut?" (hlm. 157)

(4) "Dana pelaksanaan pertemuan itu sudah bisa kami serahkan sekarang." (hlm. 160)

Berdasarkan konteksnya, data (3) dan (4) merupakan percakapan antara Juragan Kantang dana Pak Burhan. Pak Burhan telah tiba di rumah Juragan Kantang untuk mengajaknya menjadi tim sukses untuk pemilu nanti. Dari data (3) terdapat kata kami yang merujuk pada Juragan Kantang dan orang-orang Bajo yang ada di Kampung Mekar. Pada data (4) terdapat kata kami yang merujuk pada Kong Candra dan Pak Burhan. Penggunaan kata kami pada data (3) dan (4) untuk menyatakan dua orang atau lebih yang mencakup pembicara dan orang lain dipihaknya.

\subsubsection{Deiksis Persona Kedua 4.1.2.1 Deiksis Persona Kedua Tunggal}

Tabel Frekuensi Penggunaan Bentuk Deiksis Persona Kedua Tunggal

\begin{tabular}{|c|c|c|}
\hline No & $\begin{array}{c}\text { Bentuk Deiksis } \\
\text { Persona Kedua } \\
\text { Tunggal }\end{array}$ & $\begin{array}{c}\text { Frekuensi } \\
\text { Penggunaa } \\
\text { nnya }\end{array}$ \\
\hline 1. & kamu & 6 \\
\hline & Jumlah & 6 \\
\hline
\end{tabular}

1) Deiksis persona kedua tunggal bentuk kamu

Bentuk kamu mmerupakkan deiksis persona kedua tunggal karena merujuk kepada lawan bicara. Data mengenai deiksis persona kedua tunggal bentuk kamu sebagai berikut.

(1) "Kalau kamu hendak membunuh adikmu ini, nanti kalau aku sedang tidak di rumah" (hlm. 97)

(2) "Bukannya aku tidak senang kamu bergaul...." (hlm. 97)

Berdasarkan konteksnya data (1) dan (2) merupakan tuturan yang terjadi di rumah Jayadi. Istri Jayadi, Hasnah memarahi Jayadi karena ingin memukul Liana. Setelah Hasnah memarahinya, Jayadi mulai mereda amarahnya kepada Liana. Pada data (1) dan (2) terdapat kata kamu yang merupakan bentuk dari deiksis persona kedua tunggal. Pada data (1) kata kamu merujuk pada Jayadi. Pada data (2) kata kamu merujuk pada tokoh Liana. Pada data (1) dan (2) kata kamu digunakan untuk menunjukkan bahwa tuturan terjadi pada saat situasi tidak formal karena antara penutur dan lawan tutur saling mengenal satu sama lain.

\subsubsection{Deiksis Persona Kedua Jamak}

Tabel Frekuensi Penggunaan Bentuk Deiksis Persona Kedua Jamak

\begin{tabular}{|c|c|c|}
\hline No & $\begin{array}{c}\text { Bentuk Deiksis } \\
\text { Persona Kedua } \\
\text { Jamak }\end{array}$ & $\begin{array}{c}\text { Frekuensi } \\
\text { Penggunaann } \\
\text { ya }\end{array}$ \\
\hline 1. & kalian & 2 \\
\hline & Jumlah & 2 \\
\hline
\end{tabular}

Berikut akan dipaparkan data bentuk deiksis persona kedua jamak yang ditemukan.

(1) "Kalian toh sudah tahu kalau Liana tidak serupa dengan anakanak di Kampung Mekar ini." (hlm. 177)

(2) “...Kalau sejak awal kamu sudah tahu pertalian kalian, pasti perasaanmu terhadap Liana akan lain...." (hlm. 182)

Berdasarkan konteksnya, tuturan pada data (1) dan (2) dituturkan oleh 
Sandro Dama. Ia menceritakan tentang Liana yang bukanlah asli orang Bajo. Liana bukanlah adik kandung Jayadi. Sandro Dama memberi pengertian bahwa jika Jayadi dan Awing tau sejak awal tentang Liana, maka perasaan mereka ke Liana pasti akan berbeda. Deiksis persona jamak hanya memiliki satu bentuk, yaitu kalian. Bentuk kalian merujuk pada lawan tutur lebih dari satu orang. Pada data (1) dan (2) terdapat kata kalian yang memiliki rujukan berbeda. Pada data (1) kata kalian merujuk pada tokoh Jayadi, Awing, dan Liana. Kata kalian pada data (2) merujuk pada tokoh Jayadi dan Liana.

\subsubsection{Deiksis Persona Ketiga \\ 4.1.3.1 Deiksis Persona Ketiga Tunggal}

Tabel Frekuensi Penggunaan Bentuk Deiksis Persona Ketiga Tunggal

\begin{tabular}{|c|c|c|}
\hline No & $\begin{array}{c}\text { Bentuk Deiksis } \\
\text { Persona Ketiga } \\
\text { Tunggal }\end{array}$ & $\begin{array}{c}\text { Frekuensi } \\
\text { Penggunaanny } \\
\text { a }\end{array}$ \\
\hline 1. & dia & 6 \\
\hline \multicolumn{2}{|c|}{ Jumlah } & 6 \\
\hline
\end{tabular}

Berikut akan dipaparkan data bentuk deiksis persona ketiga tunggal yang telah ditemukan.

(1)“...Kalau dia lelaki, pasti playboy...." (hlm. 78)

(2) “...Dan kalau dia perempuan, pasti tukang selingkuh.” (hlm. 78)

Deiksis persona ketiga jamak bentuk dia merujuk pada orang yang tidak berada dalam pihak penutur atau lawan tutur yang sifatnya tunggal. Berdasarkan konteksnya, tuturan pada data (1) dan (2) dituturkan oleh Awing pada saat ia mengatakan pada Liana bahwa dirinya bukanlah lelaki yang suka bermanis-manis dan suka merayu. Pada data (1) kata dia merujuk pada tokoh dia (laki-laki).
Pada data (2) kata dia merujuk pada tokoh dia (perempuan).

\subsection{Deiksis Tempat}

Tabel Frekuensi Penggunaan Bentuk Deiksis Tempat

\begin{tabular}{|c|c|c|}
\hline $\begin{array}{c}\mathrm{N} \\
\mathrm{o}\end{array}$ & $\begin{array}{c}\text { Bentuk Deiksis } \\
\text { Tempat }\end{array}$ & $\begin{array}{c}\text { Frekuensi } \\
\text { Penggunaannya }\end{array}$ \\
\hline 1. & di sini & 8 \\
\hline 2. & di sana & 2 \\
\hline 3. & di situ & 2 \\
\hline 4. & ke sini & 2 \\
\hline & Jumlah & 14 \\
\hline
\end{tabular}

1) Deiksis tempat bentuk di sini

Bentuk di sini merupakan bentuk deiksis tempat yang merujuk pada lokasi tempat penutur berada. Data tentang deiksis tempat bentuk di sini adalah sebagai berikut.

(1) "Siapa yang ambil dayung di sini?" (hlm. 10)

"Dia singgah di sini pinjam dayung. Mau menyuluh katanya." (hlm. 10)

Berdasarkan konteksnya, tuturan pada data (1) dan (2) merupakan percakapan antara Awing dan Ibunya. Awing dari beranda belakang rumahnya yang melihat dayungnya tidak ada di sana, ia langsung bertanya kepada ibunya.

\subsection{Deiksis Waktu}

\subsubsection{Deiksis Waktu Lampau}

Frekuensi Penggunaan Bentuk Deiksis Waktu Lampau

\begin{tabular}{|c|c|c|}
\hline No. & $\begin{array}{c}\text { Bentuk } \\
\text { Deiksis } \\
\text { Waktu }\end{array}$ & $\begin{array}{c}\text { Frekuensi } \\
\text { Penggunaannya }\end{array}$ \\
\hline 1. & kemarin & 2 \\
\hline 2. & tadi & 8 \\
\hline \multicolumn{2}{|c|}{ Jumlah } & 10 \\
\hline
\end{tabular}

1) Deiksis waktu lampau bentuk kemarin

Deiksis waktu lampau bentuk kemarin merupakan bentuk deiksis waktu lampau yang merujuk pada waktu sebelum tuturan dituturkan oleh penutur kepada lawan tutur. Data 
tentang deiksis waktu lampau bentuk kemarin adalah sebagai berikut.

(1) "Kemarin masih ada," kata lelaki itu lagi. (hlm. 10)

(2) "Kemarin sore dia pasang pukat, tapi tidak dapat ikan," (hlm. 10)

Deiksis waktu lampau bentuk kemarin pada data (1) dan data (2) memiliki rujukan yang berbeda. Meskipun bentuk kemarin pada data (1) dan (2) sama-sama merujuk pada waktu sebelum tuturan tersebut dituturkan oleh penutur kepada lawan tutur namun memiliki rujukan waktu yang berbeda berdasarkan konteks masing-masing tuturan . Bentuk kemarin pada data (1) merujuk pada waktu sebelum tuturan tersebut dituturkan. Berdasarkan konteksnya, tuturan tersebut dituturkan oleh Awing pada saat ia mencari dayungnya di beranda belakang rumahnya. Bentuk kemarin pada data (2) merujuk pada waktu sebelum tuturan tersebut dituturkan yang merujuk pada sore hari. Berdasarkan konteksnya, tuturan tersebut dituturkan oleh ibu Awing.

2) Deiksis waktu lampau bentuk tadi

Deiksis waktu lampau bentuk tadi merupakan bentuk deiksis waktu lampau yang merujuk pada waktu sebelum tuturan dituturkan oleh penutur kepada lawan tutur. Data tentang deiksis waktu lampau bentuk tadi adalah sebagai berikut.

(1) "Tadi siang saya ke polsek, suratnya sudah diketik, tinggal menunggu tanda tangan Kapolsek," (hlm. 51)

(2) Apa kata Sandro Dama tadi? (hlm. 53)

Kata tadi pada data (1) dan (2) memiliki rujukan yang berbeda. Meskipun bentuk tadi pada data (1) dan (2) sama-sama merujuk pada waktu sebelum tuturan tersebut dituturkan oleh penutur kepada lawan tutur, namun memiliki rujukan waktu yang berbeda berdasarkan konteks masing-masing tuturan. Bentuk tadi pada data (1) merujuk pada waktu sebelum tuturan tersebut dituturkan. Berdasarkan konteksnya, tuturan tersebut dituturkan oleh kepala desa ketika ia ditugaskan untuk ke polsek. Kata tadi pada data (2) merujuk pada saat sebelum tuturan tersebut dituturkan.

\subsubsection{Deiksis Waktu Mendatang}

Tabel Frekuensi Penggunaan Bentuk Deiksis Waktu Mendatang

\begin{tabular}{|c|c|c|}
\hline No & $\begin{array}{c}\text { Bentuk } \\
\text { Deiksis } \\
\text { Waktu }\end{array}$ & $\begin{array}{c}\text { Frekuensi } \\
\text { Penggunaannya }\end{array}$ \\
\hline 1. & nanti & 8 \\
\hline \multicolumn{2}{|c|}{ Jumlah } & 8 \\
\hline
\end{tabular}

Data tentang deiksis waktu mendatang bentuk nanti adalah sebagai berikut.

(1) "Soal keberatan Bapak-Ibu sekalian terhadap Liana, nanti saya sampaikan kepadanya." (hlm. 130)

(2) “...Apakah Bapak-Ibu mau anak kalian nanti tidak berpendidikan..." (hlm. 130)

Berdasarkan konteksnya, tuturan pada data (1) dan (2) terjadi di sekolah pada saat orang tua siswa meminta Liana untuk berhenti mengajar di sekolah tersebut. Tertapi Pak Nurdi selaku kepala sekolah tetap mempertahankan Liana karena menurutnya Liana tidak salah. Kata nanti pada data (1) merujuk pada waktu setelah tuturan tersebut terjadi, yaitu setelah orang tua murid tenang dan bubar dari sekolah. Kata nanti pada data (2) merujuk pada waktu setelah tuturan tersebut dituturkan dalam kurun waktu yang belum pasti. 


\subsection{Deiksis Wacana}

Tabel Frekuensi Penggunaan Deiksis

Wacana

\begin{tabular}{|c|c|c|}
\hline No & $\begin{array}{c}\text { Bentuk } \\
\text { Deiksis } \\
\text { Wacana }\end{array}$ & $\begin{array}{c}\text { Frekuensi } \\
\text { Penggunaannya }\end{array}$ \\
\hline 1. & itu & 8 \\
\hline 2. & -nya & 4 \\
\hline \multicolumn{2}{|c|}{ Jumlah } & 12 \\
\hline
\end{tabular}

1) Deiksis wacana bentuk itu

Deiksis wacana bentuk itu merujuk kepada hal yang sudah diungkapkan. Data tentang deiksis wacana bentuk itu adalah sebagai berikut.

(1)Sejenak matanya tertumbuk pada gambar Ki Hajar Dewantara yang tergantung di dinding. Ia menatap mata tokoh pendidikan itu (hlm. 26)

(2)Dari segi posisis, keberadaan Kampung Mekar kurang strategis. Kampung itu membentang seperti garis lurus,... (hlm. 33)

Bentuk itu pada data (1) dan (2) merupakan deiksis wacana anafora yang merujuk kepada hal yang sudah diungkapkan. Kata itu pada data (1) merujuk pada gambar $\mathrm{Ki}$ Hajar Dewantara. Berdasarkan konteksnya, Liana sedang berada di ruanggannya. Ia memikirkan pendidikan di kampungnya sambil melihat gambar tokoh pendidikan, $\mathrm{Ki}$ Hajar Dewantara. Kata itu pada data (2) merujuk pada Kampung Mekar.

2) Deiksis wacana bentuk -nya

Deiksis wacana anafora -nya merujuk kepada hal yang sudah diungkapkan. Data tentang deiksis wacana anafora -nya adalah sebagai berikut.

(3) Salah seorang yang masih memegang teguh nilai-nilai luhur tradisional Bajo adalah Sandro Dama. Usianya sulit ditebak, mungkin sekitar delapan puluh tahun (hlm. 35)

(10) "Soal keberatan Bapak-Ibu sekalian terhadap Liana, nanti saya sampaikan kepadanya." (hlm. 130)

Bentuk -nya pada data (3) dan (10) merupakan deiksis wacana anafora yang merujuk kepada hal yang sudah diungkapkan. Bentuk -nya pada data (3) merujuk pada wacana sebelumnya, yaitu pada tokoh Sandro Dama. Bentuk -nya pada data (10) merujuk pada wacana sebelumnya, yaitu pada tokoh Liana.

\subsection{Deiksis Sosial}

Tabel 4.11

Frekuensi Penggunaan Deiksis Sosial

\begin{tabular}{|l|r|c|}
\hline No & $\begin{array}{r}\text { De } \\
\text { iks } \\
\text { is } \\
\text { W } \\
\text { ac } \\
\text { an } \\
\text { a }\end{array}$ & $\begin{array}{c}\text { Frekuensi } \\
\text { Penggun } \\
\text { aannya }\end{array}$ \\
\hline 1. & beliau & \\
\hline 2. & pak & 2 \\
\hline 3. & bapak & 2 \\
\hline \multicolumn{2}{|l|}{ Jumlah } & 6 \\
\hline
\end{tabular}

1) Deiksis sosial bentuk beliau

Deiksis sosial bentuk beliau merupakan deiksis sosial yang digunakan untuk merujuk pada orang yang dihormati. Data tentang deiksis sosial bentuk beliau sebagai berikut.

(1) “...Kata anggotanya malam ini juga beliau kembali." (hlm. 51)

(5)“...Beliau hendak mendengarkan

keinginan-keinginan kita..." (hlm. 167)

Kata beliau pada data (1) merujuk pada pak kapolsek. Kata beliau pada data (1) digunakan untuk merujuk sesorang yang memiliki jabatan dan dihormati. Berdasarkan konteksnya tuturan tersebut terjadi ketika Sahili diberikan tugas untuk membawa surat 
keramaian ke polsek untuk acara pernikahan Leman dan Sennang. Kata beliau pada data (5) merupakan deiksis sosial yang digunakan untuk menjaga sopan santun dalam berbahasa. Pada data (5) kata beliau merujuk pada calon anggota dewan yang bersosialisasi di Kampung Mekar, yaitu Pak Burhan.

2) Deiksis sosial bentuk pak

Data tentang deiksis sosial bentuk pak sebagai berikut.

(2) "Saya membawa surat ini, Pak. Bacalah dulu." (hlm. 68)

(4)"Pak kepala, kami ke sini bukan mau minta nasehat. Kami mau anak-anak kami, Pak." (h.130)

Kata pak pada data (2) merujuk pada pak camat. Kata pak merujuk pada laki-laki yang yang dipandang lebih tua dan dihormati oleh penutur. Berdasarkan konteksnya, tuturan tersebut terjadi di kantor camat ketika Liana membawa surat pemberitahuan tentang program Tamasya Terumbu Karang yang akan dilaksanakannya. Kata pak pada data (4) merujuk pada Pak Nurdin. Kata pak merujuk pada Pak Nurdin karena ia memiliki jabatan sebagai kepala sekolah atau orang yang di hormati.

\section{PENUTUP}

\subsection{Kesimpulan}

Berdasarkan hasil dan pembahasan penelitian yang telah dilakukan pada data dari dialog dalam novel Kidung dari Negeri Apung karya Arsyad Salam yang mengandung deiksis ditemukan jenisjenis deiksis persona, deiksis tempat, deiksis waktu, deiksis wacana, dan deiksis sosial. Jumlah deiksis yang ditemukan dalam novel Kidung dari Negeri Apung Karya Arsyad Salam, yaitu 140 data.
Bentuk deiksis persona yang ditemukan, yaitu deiksis persona pertama tunggal yang terdiri dari bentuk saya, aku, -ku, dan ku-, deiksis persona pertama jamak terdiri dari bentuk kita dan bentuk kami, deiksis persona kedua tunggal, yaitu bentuk kamu, deiksis persona kedua jamak bentuk kalian, dan deiksis persona ketiga tunggal bentuk dia Bentuk deiksis tempat, yaitu di sini, di sana, di situ, dan ke sini. Bentuk deiksis waktu, yaitu kemarin, tadi, dan nanti. Bentuk deiksis wacana, yaitu bentuk itu dan bentuk -nya. Bentuk deiksis sosial, yaitu bentuk beliau, pak, dan bapak.

Pengguanaan deiksis dalam novel Kidung dari Negeri Apung karya Arsyad Salam sangat didukung oleh penggunaan deiksis dalam pengembangan ceritanya. Dalam penelitian ini, deiksis yang ditemukan tidak mengalami kesalahan dalam penggunaannya. Jenis-jenis deiksis yang digunakan, yaitu deiksis persona sebanyak 90 data, deiksis tempat sebanyak 14 data, deiksis waktu sebanyak 18 data, deiksis wacana sebanyak 12 data dan deiksis sosial sebanyak 6 data.

\subsection{Saran}

Berdasarkan pembahasan dalam penelitian yang telah dilakukan dalam novel Kidung dari Negeri Apung karya Arsyad Salam, penulis menyarankan bagi peneliti selanjutnya yang hendak mengambil kajian yang relevan, agar melanjutkan penelitian ini dengan menghubungkannya dengan pembelajaran sastra di sekolah. Penelitian ini juga bisa dihubungkan dengan pembelajaran bahasa Indonesia dalam hal penggunaan deiksis yang dikembangkan menjadi pemilihan 
kata sehingga dapat diimplikasikan pada pembelajaran menulis.

\section{DAFTAR PUSTAKA}

Chaer, Abdul. 2003. Linguistik Umum. Jakarta: PT. Rineka Cipta.

Dardjowidjojo, Soenjono. 2012. Psikolinguistik: Pengantar Pemahaman Bahasa Manusia. Jakarta: Yayasan Pustaka Obor Indonesia.

Mihadja, Ratih. 2012. Buku Pintar Sastra Indonesia. Jakarta Timur: Laskar Aksara

Mustika, Rahma Rahayu. 2018. Deiksis dalam Novel Ayah Karya Andrea Hirata serta Pemanfaatannya sebagai Bahan Ajar Pembelajaran Bahasa dan Sastra Indonesia di SMA. Skripsi. Jakarta: UIN Syarif Hidayatullah.

Diakses di http://repository.uinj kt.ac.id/dspace/bitstream/12345 6789/39946/2/Rahma\%20Rahay u-FITK pada tanggal 15 Oktober 2018.

Nurgiyantoro, Burhan. 2013. Teori Pengkajian Fiksi. Yogyakarta: Gadjah Mada University Press.

Purwo, Bambang Kaswanti. 1984. Deiksis dalam Bahasa Indonesia. Jakarta: PN Balai Pustaka.

Putrayasa, Ida Bagus. 2014. Pragmatik. Yogyakarta: Graha Ilmu .

Ratna, Nyoman Kutha, 2008. Teori, Metode, dan Teknik Penelitian Sastra. Celeban Timur: Pustaka Pelajar.

Salam, Arsyad. 2015. Kidung dari Negeri Apung. Jakarta: PT. Gramedia Pustaka Utama.
Suhardi. 2013. Pengantar Linguistik Umum. Jogjakarta: Ar-Ruzz Media.

Surastina. 2018. Pengkajian Wacana. Yogyakarta: Elmatera.

Surastina. Pengantar Semantik dan Pragmatik. Yogyakarta: Elmatera.

Tarigan, Henry Guntur. 1990. Pengajaran Pragmatik. Bandung: Angkasa

Yudiono. 2007. Pengantar Sejarah Sastra Indonesia. Jakarta: PT Grasindo.

Yule, George. 2014. Pragmatik. Yogyakarta: Pustaka Pelajar.

Zaim, M. 2014. Metode Penelitian Bahasa: Pendekatan Struktural. Padang: FBS UNP Press Padang. 